\title{
DEVELOPMENT OF COTTAGE CHEESE TECHNOLOGY USING WHEY BROTH OF LINDER FLOWERS
}

\author{
Taisia Ryzhkova \\ Department of processing technology and standardization of livestock products \\ Kharkiv State Zooveterinary Academy \\ 1 Akademichna str., Mala Danylivka, Dergachivsky district, Kharkiv region, Ukraine, 62341 \\ rujkova.ua@gmail.com \\ Galina Dyukareva \\ Department of merchandising in customs affairs \\ Kharkiv State University of Food Technology and Trade \\ 333 Klochkivska str., Kharkiv, Ukraine, 61051 \\ dykareva.gala@gmail.com \\ Vasily Prudnikov \\ Department of Technology of Processing and Standardization of Livestock Products \\ Kharkiv State Zooveterinary Academy \\ 1 Akademichna str., Mala Danylivka, Dergachivsky district, Kharkiv region, Ukraine, 62341 \\ prudnikov2648@gmail.com \\ Iryna Goncharova \\ Department of Animal Breeding, Genetics, Biotechnology \\ Kharkiv State Zooveterinary Academy \\ 1 Akademichna str., Mala Danylivka, Dergachivsky district, Kharkiv region, Ukraine, 62341 \\ irina.i.goncharova@gmail.com
}

\begin{abstract}
The article presents research results of determining the rational amount of whey broth of linden flowers that favored the increase of the goat cottage cheese quality after adding to cheese seeds.

It was established, that under the influence of the rational amount of $10-20 \%$ of broth, introduced to cheese seeds of development batches (D 1, D 2) of the products at its setting (instead of the same amount of eliminated cheese whey), there took place the increase of the protein content by $0,3,0,5 \%$ and moisture by $0,6,1,7 \%$, comparing with the control.

The use of the rational amount of broth in development batches favored the increase of the product output of $100 \mathrm{~kg}$ of skimmed milk by $0,6,0,8 \%$, respectively, comparing with the control.

Whey broth of linden flowers also stimulated the development of the healthy microflora, which amount in development batches of the product (D 1-D 2) was higher in 2,5 and 2,8 times, comparing with an analogous result in the control.

It maximally bring commodity parameters of development batches of cottage cheese to requirements of the product, manufactured of cow milk, and increases the number of consumers of goat milk products.
\end{abstract}

Keywords: water-thermal processing; peeled grains; boiling coefficient; solidity of grains.

\section{Introduction}

Sour milk beverages, pasteurized, condensed milk, ice-cream and also soap, lotions and sweets are produced of goat and ovine milk throughout the world together with popular cheeses and yoghurts. At that the increase of production volumes of products of goat and ovine milk is restrained by the existent problem: presence of the "goaty" and "ovine" smell in them, correspondingly [1].

Manifestations of the typical goaty flavor are considered as a qualitative sign only in several types of goat cheeses. Specific peculiarities of organoleptic parameters of milk restrain consumption of products of goat milk by most consumers of milk products [2]. 
That is why efforts of scientists and specialists of milk-processing enterprises are directed on searching for ways that allow to decrease manifestations of the smack and smell of goat suint in fermented milk products, including, cottage cheese.

The technology of goat yearning cheese is the closest to solving the problem of increasing the quality of goat milk cheese [3].

The aim of the aforesaid study was to select optimal types of leavens and their combinative associations for decreasing the smack and smell of goat suint in a product. The most effective decrease of manifestations of specific peculiarities of goat milk at producing yearning cheese was attained by the traditional leaven, used for producing yearning cheeses - «CMC», of acidophilic and propionic acid bacteria in ratio: 55:25:20\%.

Shortcomings of this way include the necessity of preparing three leaven types - separately. And then to form leavening associations of them. It needs not only additional consumption of milk raw materials and bacterial preparations, but also efforts and time. The aforesaid testifies that the presence of the aforesaid shortcomings of the biotechnology of the aforesaid cheese types needs searching for new biotechnological approaches [3].

For increasing the quality of cheese of goat milk, extracts of five spices and herbs were introduced to its composition. There was studied the antibacterial effectiveness of five spices and herbal extracts (cinnamon stick, oregano, cloves, pomegranate and grape skin) against Listeria monocytogenes, Staphylococcus aureus and Salmonella enterica in cheese, kept at room temperature $\left(\sim 23{ }^{\circ} \mathrm{C}\right)$.

The results demonstrated that all five vegetable extracts are effective against three food pathogens in cheese. The enrichment with these extracts increased the stability of cheese to lipid oxidation. Cloves demonstrated the high antibacterial and antioxidant activity. The decrease of the number of pathogens that contain food and braking of lipids oxidation in cheese demonstrated that extracts of these plants (especially cloves) have the potential as food preservatives with natural food products [4].

There were conducted the researches for estimating the influence of the extract of cranberry fruits on the chemical composition, ripening parameters, oxidative stabilities and microbiological and also organoleptic properties of goat cottage cheese during the storage period during 8 weeks at temperature $5 \pm 2{ }^{\circ} \mathrm{C}$ with adding different concentrations of the red bilberry extract powder $(500,750$ and 1000 m.p./ $1 \mathrm{t}$ of milk). The use of the cranberry extract at the concentration less than $750 \mathrm{~m} . \mathrm{p}$. for $1 \mathrm{t}$ of milk had the essential influence on the increase of the leaving microflora amount. Fresh and stored cheese, processed by the cranberry extract, contained much less amount of psychotropic, enterococcus, proteolytic, lipolytic bacteria and also amount of yeast and mould fungi, than control cheese.

But the shortcoming of the method is the increase of cheese titrated acidity, cranberry smack, color tints in cheese samples of development batches of the product [5].

The studies concentrated on the development of a new type of cottage cheese that contains spices with acceptable sensor properties, increased biological value and long storage term. There were produced thirty types of cheese with adding fresh or dry parsley, dill, pepper, garlic and rosemary. There was estimated the characteristic of phenol compounds, antioxidant capacity and antibacterial activity of the spices and cheese samples [6].

Cheese that contains fresh pepper and fresh and dry herbs demonstrated perfect organoleptic properties. The best results were obtained with fresh sweet pepper.

The highest antioxidant and antibacterial activity was inherent to dry rosemary. That is why its composition included the high mass share of organic acids and also flavonoids and phenol diterpenes. The plant extracts, studied under the laboratory and production conditions, influenced the decrease of the amount of food pathogens, such as Salmonella Typhimurium, colon bacillus, golden staphylococcus and Listeria. The aforesaid testifies to the presence of the potential of vegetable extracts as natural food preservatives and antioxidants [6]. But a shortcoming of enriching goat cottage cheese with spices and vegetables is the acquired smack of herbs and vegetables, color tints, not inherent to cottage cheese of goat milk.

For estimating food properties, minerals and content of heavy metals, there were studied ten most popular and known varieties of plants of Lamiaceae generis, used in production of local cheese. 
This research revealed essential changes in the content of minerals among the studied types of plants.

The composition of most studied plants included such mineral compounds as $\mathrm{Fe}, \mathrm{Cu}, \mathrm{Ca}$, $\mathrm{K}$, Mn and $\mathrm{Zn}$, well-known for their important for health support. The highest concentration of toxic heavy metals, including chrome $\left(1,72 \mathrm{mg} \mathrm{kg}^{-1}\right)$ was revealed in Mentha longifolia. The highest cobalt content $\left(1,14 \mathrm{mg} \mathrm{kg}^{-1}\right)$ was inherent to Ziziphora capitata. The results of this study allow to assume that the use of these types of plants at producing cheese doesn't favor the increase of toxicity of heavy metals, but may be useful at treating the deficit of microelements [7].

The set contains 58 samples of Polish medical herbal materials: samples of herbs, flowers and bark; there were determined concentrations of total nitrogen and phosphorus in both aforesaid dry samples and in their water extracts. Taking into account the dry weight of samples, the total content of nitrogen included values from 4,69 to $27,42 \mathrm{mg} / \mathrm{g}$ in plants, from 11,10 to $40,67 \mathrm{mg} / \mathrm{g}-$ in flowers and from 5,92 to $9,77 \mathrm{mg} / \mathrm{g}$ - in bark samples. The total content of phosphorus was revealed within $2,70-10,19 \mathrm{mg} / \mathrm{g}$ in herbs: from 2,15 to $8,82 \mathrm{mg} / \mathrm{g}$ - in flowers and from 0,46 to $1,30 \mathrm{mg} / \mathrm{g}-$ in bark. In average nitrate nitrogen was a share from 2,6 \% (in flowers), to $15,1 \%$ (in bark) from the total amount of nitrogen. Whereas, inorganic phosphate phosphorus was from $28,3 \%$ (in herbs) to $60,2 \%$ (in bark) from the total amount of this element. The comparison of potentially bio-accessible inorganic forms of nitrogen and phosphorus with food norms of WHO/FAO and RDA testifies that samples of vegetable materials can deliver to people essential amounts of $\mathrm{N}$ and $\mathrm{P}$ [8].

The biological activity of many dry medical herbs, including thyme, is described, but mainly connected with its essential oils and used in folk medicine for preparing broth in home conditions. But information about studies on determining the biological activity in its broth is extremely limited. That is why scientists conducted additional studies on determining manifestations of antioxidant and antibacterial properties of thyme broth and its water-alcohol extracts [9]. The content of phenol compounds was also determined.

Thyme broth demonstrated the highest concentration of phenol compounds (phenol acids or flavonoids), comparing with the water-alcohol extract.

In general, all samples of preparations of broth and water-alcohol extracts were effective against gram-positive (Staphylococcus aureus and Staphylococcus epidermidis) and gram-negative (Escherichia coli, Klebsiella spp., Pseudomonas aeruginosa, Enterococcus aerogenes, Proteus vulgaris та Enterobacter sakazakii). But the most expressed effect of inhibiting pathogenic microorganisms took place under the effect of thyme broth [9].

There were conducted the studies of determining the biological activity of Matricaria recutita L. (chamomile) broth. It was established, that camomile broth has antioxidant activity: inhibits peroxide oxidation of lipids. It also prevents the development of enteric bacteria and fungi.

Herbal broth is used at producing sour-milk cheese. The food composition, color and antioxidant activity of all cheese samples were estimated during the storage time. Camomile broth (natural biologically active ingredient) didn't essentially change profiles of lipids and fatty acids in cheese, but increased the antioxidant potential of the product at storage. Moreover, it increased its storage term, because only after 14 days of storage there were fixed degradation signs of only control samples. The development of this new functional milk product gives grounds for widening the assortment of milk products with medical herbs for preventing their spoilage [10].

There is a global tendency to healthy food products, mainly including natural biologically active ingredients that replace synthetic supplements.

Previous studies discovered that extracts of Foeniculum vulgare Mill. (fennel) and Matricaria recutita L. (camomile) retained saturated properties and increased antioxidant activity of sour-milk cheese. At that the effect was limited by 7 days.

Correspondingly, water extracts of these plants were microcapsulated in alginates and included in cheese for attaining the increased biological activity.

Ordinary cheese and one, functionalized by the direct addition of free broth were prepared and compared.

Despite plant types, "functionalization" factor had no essential influence on food parameters that is also proved by the linear discriminant analysis, where these parameters were not chosen 
as discriminant variables. At the same time models, functionalized by microcapsulated extracts, demonstrated the higher antioxidant activity after 7-th day, in such a way demonstrating that the main aim of this experimental work was attained [11].

Information about demonstration of antibacterial properties by many dry herbs, extracts of herbs and vegetables and broth of them, attracted our attention to linden flowers.

Linder flowers are distributed by drugstore nets because of their medical properties.

The pleasant smell and a bit yellow color of linden flowers are, from our point of view, the most suitable material for preparing whey broth of them and its introduction in the process of manufacturing goat cottage cheese.

The aim of the work is the development of the cottage cheese technology using linden flower broth, directed on increasing the cottage cheese quality (increase of the density of cheese seeds and product output of $100 \mathrm{~kg}$ of skimmed milk, decrease of the content of low-molecular fatty acids, responsible for the goat suint smell and taste, without changing the traditional white color of cottage cheese).

The following tasks were set for attaining this aim:

- to increase the cheese seeds density and to decrease losses of its components with cheese whey;

- to increase the product output of $100 \mathrm{~kg}$ of goat milk;

- to increase the amount of healthy leavening microflora in the composition of development batches of the product;

- to decrease the number of low-molecular fatty acids that favor elimination of the goat suint taste and smell.

\section{Materials and methods of studying goat milk, control and three development batches of} cottage cheese

2. 1. Selection of samples of milk of milked goats and methods of conducting physical-chemical and biochemical studies

The milk raw material (goat milk) was processed into cottage cheese. At preparing goat cottage cheese, it was subjected to the laboratory control.

All four batches of cottage cheese (control and three development ones) of the product were prepared according to existent normative-technical documents [12].

Goat milk in the amount of $10 \mathrm{~kg}$ for each product batch was used as a milk raw material for producing cheese of the control and three development batches.

A start culture at producing control and development batches of goat cottage cheese was the leaven "CMC», produced at the state research enterprise of bacterial leavens, placed on the territory of the "Institute of food resources" in city Kyiv, Ukraine, and is used for producing cow milk cottage cheese.

Technologies of the development batches of cottage cheese (D 1-D 3) differed from the control one by the change of whey, created at setting cheese seeds, for whey broth of linden flowers in amount 10, 20 and $25 \%$. The concentration of linden flowers was determined experimentally, based on comparative data of organoleptic estimation of control and development samples of cottage cheese.

For determining physical-chemical and biochemical parameters of goat milk, there were formed groups of animals of 10 heads.

Goats of the second and third lactations were kept at the goat farm of the "Learning-scientific center" of Kharkiv State Zooveterinary Academy. The goat farm is situated in Mala Danylivka, Dergachivsky district, Kharkiv region, Ukraine. Goats of Zaanenska and Local breed were clinically healthy.

Goat milk samples were taken at the farm proportionally to the day yield for 2 adjacent days of each aforesaid experimental animal.

The taken milk samples were filtered at the farm, cooled to temperature $6 \pm 2{ }^{\circ} \mathrm{C}$. They were delivered for the study at the probationary center of the Institute of livestock of NAASU in Kulinichy, Kharkiv, Ukraine, accredited according to requirements of SSU ISO/EC 17025:2006 (ISO/IES 17025:2005, accreditation certificate No. 2T621 at the National agency of accreditation of Ukraine). 
Determination of a mass share (m. s.) of fat, protein, lactose, density and dry substances in milk samples, taken from the groups of goats and cows from the aforesaid regions of Ukraine, was conducted according to requirements of ISO 9001: 2000 instrumentally on the device «Bentley-150» (USA).

Goat milk was separated at the usual separator - cream-separator of the open type of OCE trademark, produced at the machine-building plant "Smychka", Russia, placed in the accommodation of the laboratory of the department.

The principle of cream-separator's action is based on the effect of centrifugal forces, created in its main part - drum. As a lighter milk part, cream is eliminated from the separator's drum through the upper horn, and skimmed milk - to the low one, as a heaviest one.

One of main technical parameters that characterize the separator's work is a temperature of heating milk. That is why for conducting the effective process of separating goat milk, it was heated to $43 \pm 2{ }^{\circ} \mathrm{C}$.

Skimmed milk, obtained at the separation process, is directed for processing in cottage cheese. Cream - for producing sour cream.

Physical-chemical parameters of samples of milk products were determined according to requirements, presented in the following normative documents:

- selection of samples of milk products was realized according to SSU 4834:2007 «Milk and milk products. Rules of reception, taking and preparation of samples for controlling» and SSU ISO 707:2002 «Milk and milk products. Instructions of taking samples";

- an outlook, consistence and color of the product were estimated visually, a smack and smell - organoleptically;

- a temperature was determined by SSU 6066:2008 «Milk and milk products. Methods of determination of temperature and mass-netto»;

- the calculation of somatic cells was conducted on the device of the combined model Somacount 150 and Bentley (USA) (Certificate IDA 0001461-1 of 16.12.2004 SCC);

- a density was determined by SS 3625-84 «Milk and milk products. Methods of determination of density";

- a titrated acidity was determined by SS 3624-92 «Milk and milk products. Titrimetic methods of determination of acidity";

- a mass share of moisture and dry substance in cheese - by SS 3626-73 «Milk and milk products. Methods of determination of moisture and dry substances".

Biomechanical parameters of research objects were determined according to requirements, presented in the following normative documents, including on certified devices:

- M. s. of fat was determined - by SS 5867-90 «Milk and milk products. Methods of determination of fat" and SSU ISO 1211:2002 «Milk. Gravimetric method of determination of fat content" (Control method);

- Determination of the content of free fatty acids was conducted using the fatty-acid analyzer chromatograph "Chrome-5» (country-producer USA) by SS 30418-96 «Vegetable oils. Methods of determination of fatty-acid composition";

- M. s. of total protein was determined y Kjeldahl method according to requirements of SSU ISO 8968-1 and SSU ISO 8968-5;

- Determination of the amino acid composition of the control and development batches of cottage cheese of goat milk was conducted on the automatic analyzer of amino acids AAA 339 M (Prague).

\section{2. Sanitary-bacteriological research methods}

Sanitary-bacteriological parameters of research objects were determined according to requirements, presented in the following normative documents and methods using certified devices:

- preparations of samples and dilutions for the microbiological studies were realized by SSU IDF 122C:2003 «Milk and milk products. Preparation of samples and dilutions for microbiological studies"; 
- the total number of sour-milk bacteria and separate representatives - by SS 10444.11-89 «Food products. Methods of determining microorganisms" and by SSU IDF 149A:2003 «Cultures of sour-milk leavens. Determination of type composition".

Pollution of milk and milk products by the side microflora:

- determination of the number of microorganisms - by SSU IDF 100B:2003 «Milk and milk products. Methods of determination of microorganisms' number. Method of calculation of colonies at temperature $30{ }^{\circ} \mathrm{C} »$;

- bacteria of colon bacillus group (BCBG) were determined by SSU 7140:2009 «Milk and milk products. Methods of calculation of coliforms and colon bacillus (E-coli) by plates;

- pathogenic microorganisms, including bacteria of Salmonella generis - according to SSU IDF 93A; Staphylococcus aureus in $1 \mathrm{~g}$ of cheese - according to requirements SS 30347 «Milk and milk products. Methods of determination of Staphylococcus aureus»; Listeria monocytogenes in $1 \mathrm{~g}$ of cheese - according to requirements of SSU ISO 11290-1:2003 «Microbiology of food products and forages for animals. Horizontal method of revelation and calculation of Listeria monocytogenes. Part 1. Method of revelation», SSU ISO 11290-2:2003 «Microbiology of food products and forages for animals. Horizontal method of revelation and calculation of Listeria monocytogenes. Part 2. Method of calculation".

At determining the cheese output, the milk raw material was normalized according to parameters of m.s. of fat and protein in the initial milk raw material.

Fig. 1 presents the device for determination of somatic cells of the physical-chemical composition of goat milk «Bentley Somacount 150» and «Bentley Instrumenis» (country - producer USA).

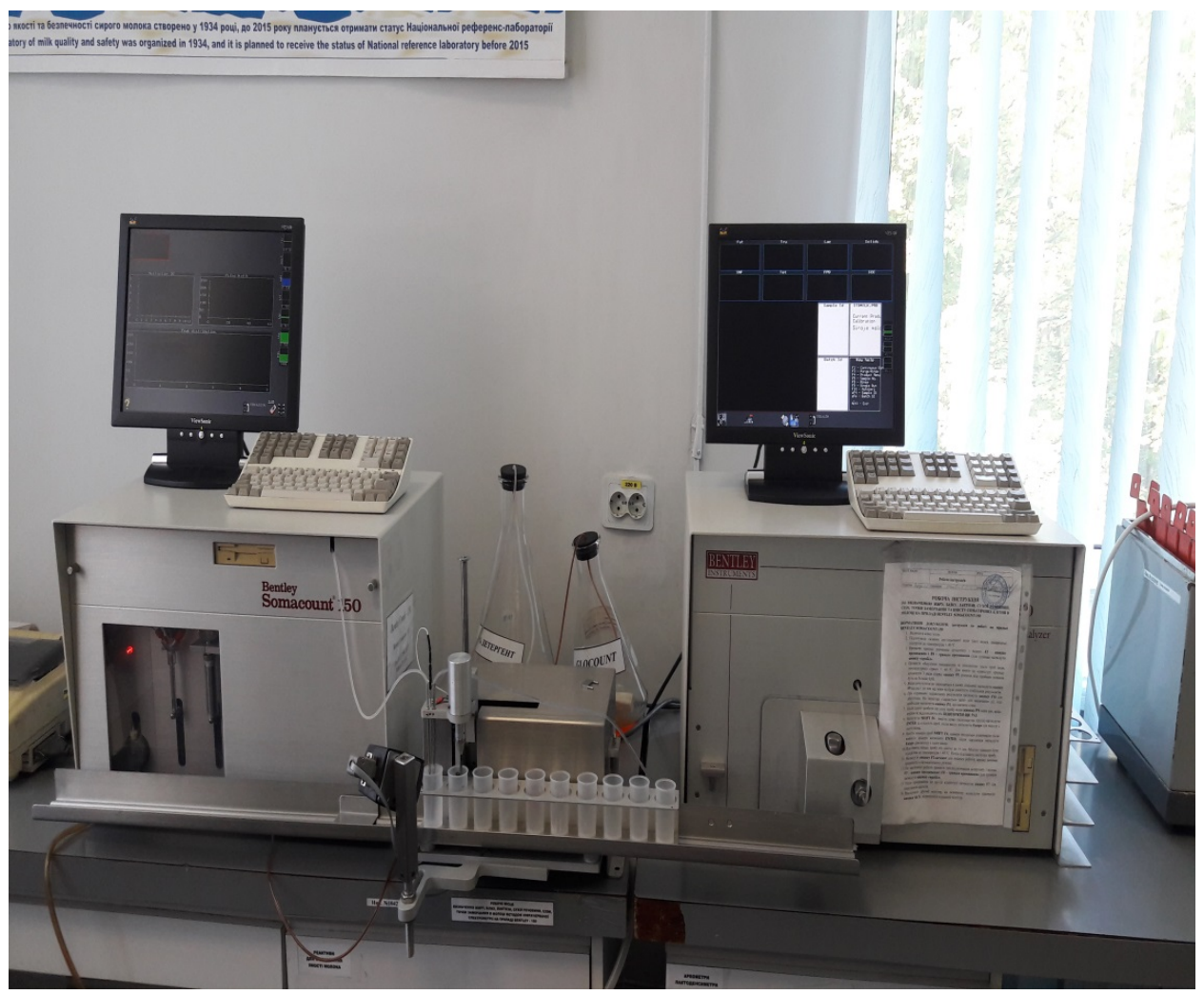

Fig. 1. device for determination of somatic cells «Bentley Somacount 150» (on the left) and for determination of physical-chemical composition of goat milk «Bentley Instrumenis» (on the right) (USA)

Fig. 2, 3 present photos of the devices, used for determining the physical-chemical composition of goat milk cheese. 


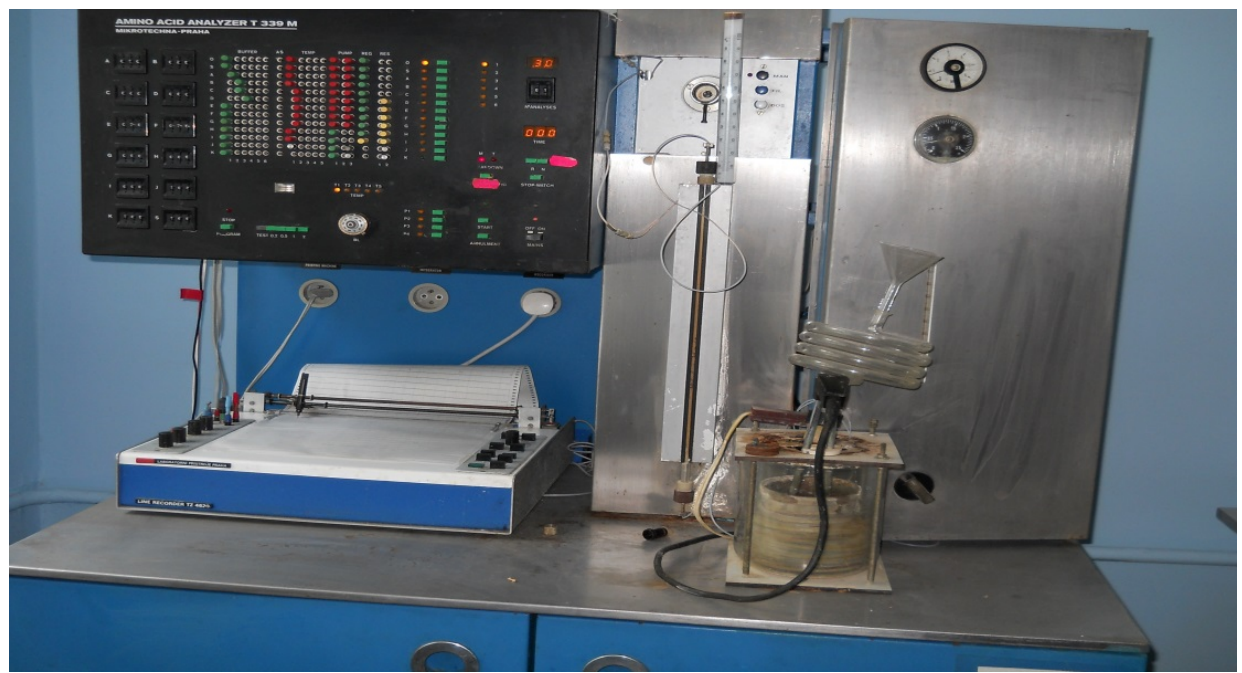

Fig. 2. Device for determination of the amino acid composition of the control and development batches of cottage cheese of goat milk - automatic analyzer of amino acids AAA 339 M (Prague)

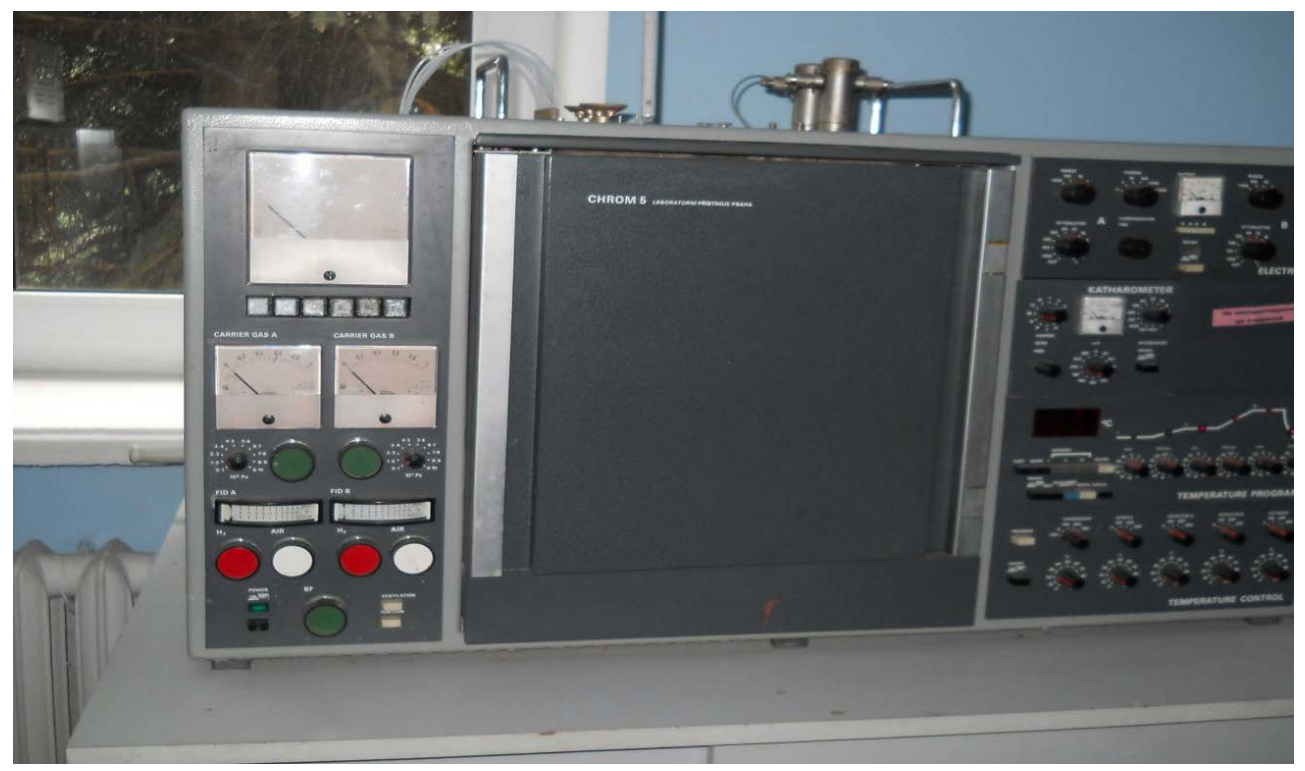

Fig. 3. Device chromatograph "Chrome-5» for determination of fatty-acid composition of the control and development batches of sour cottage cheese of goat milk (USA)

\section{Research results of physical-chemical, biochemical and sanitary-bacteriological parame- ters of soft grainy cheese of goat milk}

For producing cottage cheese, there was used goat milk of goats, kept at the "Learning-scientific center" of Kharkiv State Zooveterinary Academy. After separation, milk was set for producing cottage (grainy cheese).

Table 1 presents physical-chemical characteristics of goat milk, used for separation and transformation in cottage cheese.

The data, presented in table 1, demonstrate that physical-chemical parameters of goat milk correspond to requirements of the existent State standard of Ukraine for stored goat milk (SSU 7006:2009 «Goat milk raw material. Technical conditions" that corresponds to ISO 707:2008 «Milk and milk products - Guidance for taking samples».

The control and development batches of cheese were produced according to SSU 7518:2014 Soft cheese of goat milk. General technical conditions. [Valid of 2015-02-01] and technological instruction to it. 
Table 1

Physical-chemical composition of goat milk, used for cottage cheese and skimmed milk

\begin{tabular}{|c|c|}
\hline Parameters & Values \\
\hline M. s. of dry substances, $\%$ & 11,2 \\
\hline M. s. of protein, $\%$ & 2,9 \\
\hline M. s. of fat, \% & 3,7 \\
\hline Titrated acidity, ${ }^{\circ} \mathrm{T}$ & 15 \\
\hline \multicolumn{2}{|l|}{ Density } \\
\hline SC number, thousand $/ \mathrm{cm}^{3}$ & 50 \\
\hline Density in, $\mathrm{A}^{\circ}$ & 28 \\
\hline \multicolumn{2}{|l|}{ Skimmed milk } \\
\hline M. s. of fat, \% & 0,05 \\
\hline Density in, $\mathrm{A}^{\circ}$ & 30 \\
\hline M. s. of protein, $\%$ & 3,0 \\
\hline Titrated acidity, ${ }^{\circ} \mathrm{T}$ & 17 \\
\hline
\end{tabular}

Note: M.s. - mass share. SC - number of somatic cells

Preparation of whey broth of linden flowers was realized in the following way: 250 grams of linden flowers were placed in a thermostable chamber, poured with $9750-9900 \mathrm{~cm}^{3}$ of fat sour cheese whey, and the mixture was boiled during 5-7 $\mathrm{min}$.

Thermal processing of broth was stopped after appearance of residue of whey proteins. After that linden broth was cooled, filtered (defecated) and kept before using during no more than 24 hours at temperature $8{ }^{\circ} \mathrm{C}$.

At the end of the process of setting cheese seeds (mixing of a clot with the synchronous and successive increase of the temperature in cheese bathes to $38-40{ }^{\circ} \mathrm{C}$ ) that lasted during $20-25 \mathrm{~min}$, the share of formed cheese whey was eliminated. Especially 10, 20 and $25 \%$ of whey, formed in a bath during the aforesaid technological operation were eliminated from the development batches of cheese D 1, D 2 and D 3, respectively. Instead of eliminated whey, there were introduced 10, 20 and $25 \%$ of broth, mixing during 10-15 min. Then whey in the control cheese batch and the mixture of whey with broth in the development batches of the product was eliminated. Cottage cheese was unloaded from cheese bathes, packed in consumption packages and sent to a refrigerator chamber for cooling to $2-4^{\circ} \mathrm{C}$.

There was realized the determination of physical-chemical parameters of the control $(\mathrm{C})$ and development D 1-D 3) batches of cottage cheese with adding different amounts of linden broth. The research results are presented in Table 2.

The data of Table 2 demonstrate that introduction of whey broth of linden flowers in amount 10 and $20 \%$ to the composition of the development batches (D 1 and D 2) of goat cottage cheese favored the increase of protein m.s. by $0,3,0,5 \%$ and $0,6 \%$; moisture by $0,6,1,7$ and 4,9; titrated acidity by 3,5 and $11^{\circ} \mathrm{T}$ comparing with the control.

The absence of the reliable difference in indices of the mass share of protein and moisture between the development batch of the product D 2 and D 3 testifies to the inexpedience of increasing the broth amount to $25 \%$. At the same time the use of this amount of broth increased the titrated acidity of the development batch of cheese D 3 to $80^{\circ} \mathrm{T}$ that caused the sourish taste of it. The use of broth in amount 10, 20 and $25 \%$ favored the decrease of consumption of goat skimmed milk at processing of $100 \mathrm{~kg}$ of goat milk in cottage cheese, correspondingly less by $0,42,0,82$ and $0,92 \mathrm{~kg}$, comparing with the control. It conditioned the increase of the output of the development batches (D 1-D 3) of cheese of $100 \mathrm{~g}$ of skimmed milk, correspondingly, by $0,6,0,8$ and $0,9 \mathrm{~kg}$. 
Table 2

Physical-chemical parameters of three batches of cottage linden cheese

\begin{tabular}{|c|c|c|c|c|}
\hline \multirow{2}{*}{ Parameters } & \multicolumn{4}{|c|}{ Research results } \\
\hline & $\mathbf{C}$ & D.1 & D.2 & D.3 \\
\hline *Amount of linden broth, $\%$ & - & $10 \%$ & $20 \%$ & $25 \%$ \\
\hline M.s. of fat in dry substance of cheese, $\%$ & $20,0 \pm 1,0$ & $21,0 \pm 1,0$ & $21,5 \pm 1,0$ & $21,7 \pm 1,0$ \\
\hline M.s. of protein, $\%$ & $16,9 \pm 0,2$ & $17,2 \pm 0,2$ & $17,4 \pm 0,2$ & $17,5 \pm 0,2$ \\
\hline M.s. of moisture, $\%$ & $78,3 \pm 0,3$ & $78,9 \pm 0,3$ & $80, \pm 0,3$ & $82,5 \pm 0,3$ \\
\hline Titrated acidity, ${ }^{\circ} \mathrm{T}$ & $69,0 \pm 3,45$ & $72 \pm 3,25$ & $74 \pm 3,25$ & $80 \pm 3,25$ \\
\hline $\begin{array}{l}\text { Consumption of the mixture of skimmed milk } \\
\text { (DSMR 8,9\%) for } 100 \mathrm{~kg} \text { of cheese, in } \mathrm{t}\end{array}$ & $10,42 \pm 0,52$ & $9,80 \pm 0,47$ & $9,60 \pm 0,47$ & $9,50 \pm 0,47$ \\
\hline Output of cheese of $100 \mathrm{~kg}$ of skimmed milk, $\mathrm{kg}$ & $9,6 \pm 0,53$ & 10,2 & 10,4 & 10,5 \\
\hline
\end{tabular}

Note: M.s. - mass share; C, D. 1-D.3-control and development batches of goat cottage cheese; *Dose of herbal broth, introduced to the cheese mass instead of eliminated whey, \%

So, the rational dose of using broth of linden flowers is 10-20\% of the mass of whey, separated at producing cottage cheese. The results of the researches on determining the change of the fatty acid composition of the development batches of cheese (D1, D 2 and D 3) of cottage goat cheese, took place under the effect of broth of linden flowers, are presented on Fig. 4.

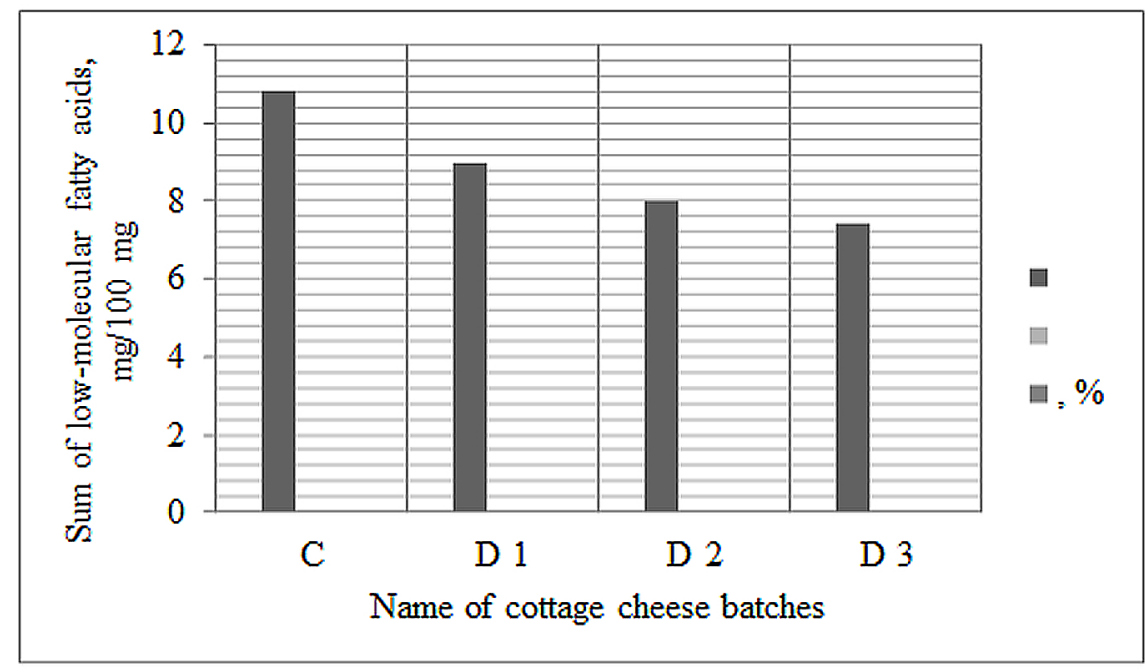

Fig. 4. Changes of the content of low-molecular fatty acids in the development batches of cottage cheese (D 1, D 2 and D3) that took place under the effect of broth of linden flowers

The graph on Fig. 4 demonstrates that the development batches of cottage cheese (D 1, D 2 and D 3) under the effect of broth of linden flowers in amount 10, 20 and $25 \%$ of the mass of whey, separated at processing of a clot (its cut in blocks) and setting of cheese seeds, underwent the decrease of the content of low-molecular fatty acids by 1,8,2,8 and 3,4\%, comparing with the control (C) .

The organoleptic estimation of the development batches (D 1-D 3) of cheese demonstrated that instead of the smack and smell of goat suint, they acquired a bit noticeable smack and smell of linden flowers. Cheese seeds became denser than in the control. At that their color in cottage cheese remained the same.

The same characteristic of cheese seeds of cottage cheese is maximally approximated to parameters of the product, manufactured of cow milk. 
There were determined microbiological parameters of the control (C) and development batches (D 1-D 3) of cottage cheese (Table 3).

Table 3

Microbiological parameters of three samples of cheese

\begin{tabular}{|c|c|c|c|}
\hline \multirow{2}{*}{ Parameter name } & \multicolumn{3}{|c|}{ Cheese batch } \\
\hline & Control (C) & Development (D.1) & Development (D.2) \\
\hline Bacteria of the group of colon bacillus (coliforms) in 0,01 of cheese & \multicolumn{3}{|c|}{ Not revealed } \\
\hline $\begin{array}{l}\text { Pathogenc microorganisms, including Salmonella generus, in } 25 \mathrm{~g} \text { of } \\
\text { the prodet }\end{array}$ & \multicolumn{3}{|c|}{ Not revealed } \\
\hline Staphylococcus aureus, in $1 \mathrm{~g}$ of cheese & \multicolumn{2}{|r|}{$1,0 \times 10^{2}$} & $1,0 \times 10^{2}$ \\
\hline Listeria monocytogenes in $1 \mathrm{~g}$ of cheese & \multicolumn{3}{|c|}{ Not revealed } \\
\hline Number of lactobacteria, NCU in $\mathrm{cm}^{3}$, no less than & $1,0 \times 10^{7}$ & $2,5 \times 10^{7}$ & $2,8 \times 10^{7}$ \\
\hline
\end{tabular}

The data of Table 3 demonstrates that the inclusion of linden flower whey broth in the technological process of the development batches (D 1 and D 2) of goat cottage cheese provided formation of the microflora, healthy for the human organism, in 2,5 and 2,8 times more respectively comparing with the control.

\section{Conclusions}

There was determined the rational amount of linden flower broth, introduced in the process of producing the development batches in amount (10-20\%) of whey, separated at setting cheese seeds, that allows:

- to increase the density of cheese seeds and to decrease losses of their components with cheese whey;

- to increase the product output of $100 \mathrm{~kg}$ of skimmed milk by $0,6-0,8 \%$;

- to increase the biological value in the development batches of goat cheese D 1 and D 2 at the expanse of increasing the population of leavening microflora in 2,5 and 2,8 times, respectively, comparing with the control; control (C).

- to decrease the number of low-molecular fatty acids by $1,8,2,8 \%$, comparing with the

It allows to increase organoleptic parameters of development batches of cottage cheese, especially to eliminate the smack and smell of goat suint in them. Although, it remains the white color of cheese dough, typical for cottage cheese, without changes.

\section{References}

[1] Pal, M., Dudhrejiya, T. P., Pinto, S. (2017). Goat milk products and their significance. Beverage \& Food World, 44 (7), 21-25.

[2] Wang, C., Wang, C., Gao, F., Xu, Y., Guo, M. (2018). Effects of polymerized whey protein on goaty flavor and texture properties of fermented goat milk in comparison with $\beta$-cyclodextrin. Journal of Dairy Research, 1-7. doi: http://doi.org/10.1017/s0022029918000742

[3] Ryzhkova, T. N., Kigel', N. F. (2015). Vybor zakvasok dlya proizvodstva sychuzhnykh syrov iz koz'ego moloka. Nauchnye trudy SWorld, 3 (40), 31-35.

[4] Shan, B., Cai, Y.-Z., Brooks, J. D., Corke, H. (2011). Potential Application of Spice and Herb Extracts as Natural Preservatives in Cheese. Journal of Medicinal Food, 14 (3), 284-290. doi: http:// doi.org/10.1089/jmf.2010.0009

[5] Khalifa, S. A., Wahdan, K. M. (2015). Improving the quality characteristics of white soft cheese using cranberry (Vaccinium macrocarpon) fruit extract. International Food Research Journal, 22 (6), $2203-$ 2211. Available at: https://search.proquest.com/openview/28eacfac94c5e28e36eeab14cdc0ele6/1?pq-origsite $=$ gscholar\&cbl $=816390$ 
[6] Josipovic, R., Medverec Knezevic, Z., Frece, J., Markov, K. et. al. (2015). Improved Properties and Microbiological Safety of Novel Cottage Cheese Containing Spices. Food Technology and Biotechnology, 53 (4), 454-462. doi: http://doi.org/10.17113/ftb.53.04.15.4029

[7] Tuncturk, M., Eryigit, T., Kaya, A. R. (2016). Nutritional properties, minerals, and selected heavy metal contents in herby cheese plants of Lamiaceae. Applied Biological Chemistry, 60 (1), 41-47. doi: http://doi.org/10.1007/s13765-016-0245-9

[8] Konieczynski, P., Wesolowski, M. (2007). Bioavailable inorganic forms of nitrogen and phosphorus in extracts of herbs, flowers and bark of medicinal plants. Chemical Speciation \& Bioavailability, 19 (3), 109-115. doi: http://doi.org/10.3184/095422907x236353

[9] Martins, N., Barros, L., Santos-Buelga, C., Silva, S., Henriques, M., Ferreira, I. C. F. R. (2015). Decoction, infusion and hydroalcoholic extract of cultivated thyme: Antioxidant and antibacterial activities, and phenolic characterisation. Food Chemistry, 167, 131-137. doi: http://doi.org/10.1016/j.foodchem.2014.06.094

[10] Caleja, C., Barros, L., Antonio, A. L., Ciric, A., Barreira, J. C. M., Sokovic, M. et. al. (2015). Development of a functional dairy food: Exploring bioactive and preservation effects of chamomile (Matricaria recutita L.). Journal of Functional Foods, 16, 114-124. doi: http://doi.org/10.1016/j.jff.2015.04.033

[11] Caleja, C., Ribeiro, A., Barros, L., Barreira, J. C. M., Antonio, A. L., Beatriz P.P. Oliveira, M. et. al. (2016). Cottage cheeses functionalized with fennel and chamomile extracts: Comparative performance between free and microencapsulated forms. Food Chemistry, 199, 720-726. doi: http://doi.org/10.1016/j.foodchem.2015.12.085

[12] Ryzhkova, T. M. (2015). DSTU 7518:2014 Syry miaki z kozynoho moloka. Zahalni tekhnichni umovy. [Chynnyi vid 2015-02-01]. Kyiv: Derzhspozhyvstandart Ukrainy, 11.

\title{
THE STUDY OF TECHNOLOGICAL PROPERTIES OF WAXY WHEAT FLOUR AND ITS INFLUENCE ON REFINED SUGAR-FREE HARDTACKS DOUGH
}

\author{
Katerina Iorgachova \\ Department of bakery, confectionary, pasta and food concentrates technology \\ Odessa National Academy of Food Technologies \\ 112 Kanatna str., Odessa, Ukraine, 65039 \\ epinchuk@ukr.net \\ Olga Makarova \\ Department of bakery, confectionary, pasta and food concentrates technology \\ Odessa National Academy of Food Technologies \\ 112 Kanatna str., Odessa, Ukraine, 65039 \\ epinchuk@ukr.net \\ Kateryna Khvostenko \\ Department of bakery, confectionary, pasta and food concentrates technology \\ Odessa National Academy of Food Technologies \\ 112 Kanatna str., Odessa, Ukraine, 65039 \\ epinchuk@ukr.net
}

\footnotetext{
Abstract

There was grounded the choice of ingredients for developing floury confectionary products without sugar and prospects of using amylose-free flour of waxy wheat and sunroot powder for their production. There were determined quality parameters of used flour, conditioned by the state of the protein-proteinase complex.

Based on studying technological properties of flour of waxy wheat, there was demonstrated the expedience of its use in the technology of products of yeasty dough, especially hardtacks, at replacing sugar for sunroot powder. There was offered to introduce
} 